\title{
Assessment of Knowledge, Perception About Transplantation and Life Changes in Renal Transplant Patients
}

\section{Böbrek Nakli Hastalarında Transplantasyon ile İlgili Bilgi, Algılama ve Yaşam Değişikliklerinin Değerlendirilmesi}

(D) Oya Bozkurt

İstanbul Yeniyüzyll University Gaziosmanpaşa Hospital Faculty of Medicine, Clinic of Mental and Neurological Diseases, İstanbul, Turkey

Abstract

Objective: The objective of the study was to determine subjective factors such as adherence to treatment, knowledge levels, individual perceptions and life-style changes with a view to determine variables that could be useful for future processes in patients undergoing kidney transplant.

Method: The study was conducted in the Nephrology Department of Gaziosmanpaşa Hospital, between January 2019 and November 2019. Fifty people aged between $18-70$ years who had undergone renal transplantation at least 3 months ago and were treated as outpatients by applying to the nephrology clinic were evaluated. A semi-structured questionnaire including questions about their knowledge regarding transplantation, life-style changes in the transplantation process and personal perceptions was administered to the patients.

Results: All patients expressed satisfaction with every step of the transplantation process. $32 \%$ of the patients were uncomfortable with medication and hospital visits and $44 \%$ were happy that dialysis was not in their life. $86 \%$ of the patients who underwent kidney transplantation reported increased quality of life after the operation and $36.7 \%$ stated that their sexual life changed positively. It was found that those who adhered to treatment mostly interrupted the use of medication (24\%), and the sexual life of men and also patients with children were significantly affected more positively by transplantation. Those who did not receive adequate information before treatment had significantly more problems with adherence to treatment.

Conclusion: It was found that the quality of life of the patients improved significantly after kidney transplantation. Men's sexuality was affected more positively by transplantation. By endeavoring to improve patients' knowledge and perceptions prior to kidney transplantation, patient satisfaction and adherence to treatment can be significantly improved.

Keywords: Renal transplantation, knowledge, individual perception, adherence to treatment

\section{Öz}

Amaç: Bu çalışmanın amacı, böbrek nakli yapılan hastalarda gelecekteki süreçler için faydalı olabilecek değişkenleri belirlemek amacıyla tedaviye uyum, bilgi düzeyleri, bireysel algılar ve yaşam tarzı değişiklikleri gibi öznel faktörleri belirlemektir.

Yöntem: Bu çalışma Gaziosmanpaşa Hastanesi Nefroloji Bölümü'nde Ocak 2019 ve Kasım 2019 tarihleri arasında yapıldı. En az 3 ay önce böbrek nakli yapılan, nefroloji kliniğine başvurarak ayakta tedavi görmekte olan, 18-70 yaşları arasında 50 kişi çalışmaya alındı. Hastalara nakil hakkındaki bilgileri, nakil sürecindeki yaşam tarzı değişiklikleri ve kişisel algılarını içeren yarı yapılandırılmış bir anket formu uygulandı.

Bulgular: Tüm hastalar, nakil işleminin her adımından memnun olduğunu belirtti. Hastaların \%32'si ilaç ve hastane ziyaretlerinden rahatsızdı ve \%44'ü diyaliz yaşamlarında olmadığı için mutluydu. Böbrek nakli yapılan hastaların \%86'sı ameliyat sonrası yaşam kalitesini arttırdığını bildirdi ve \%36,7'si cinsel yaşamlarının olumlu yönde değiştiğini belirtti. Tedaviye bağlı olanların çoğunlukla ilaç kullanımını (\%24) kesintiye uğrattığı, erkeklerin ve ayrıca çocuklu hastaların cinsel yaşantılarının transplantasyondan sonra daha olumlu etkilendiği bulundu. Tedavi öncesi yeterli bilgi alamayanların tedaviye uyumu ile ilgili olarak daha fazla problemi vardı.

Sonuç: Hastaların yaşam kalitesinin böbrek nakli sonrası anlamlı şekilde arttığı tespit edildi. Nakilden erkek cinselliği daha olumlu yönde etkilenmiştir. Hastaların böbrek nakli öncesinde bilgi ve algılarını geliştirmeye çaba göstererek, hasta memnuniyeti ve tedaviye uyum önemli ölçüde iyileştirilebilir.

Anahtar kelimeler: Böbrek nakli, bilgi, bireysel algı, tedaviye uyum

Address for Correspondence: Oya Bozkurt, İstanbul Yeniyüzyıl University Gaziosmanpaşa Hospital Faculty of Medicine, Clinic of Mental and Neurological Diseases, i̇stanbul, Turkey

E-mail: oyabozkurt2000@yahoo.com ORCID: orcid.org/0000-0002-1084-8414 Received: 12.11.2019 Accepted: 08.12.2019

Cite this article as: Bozkurt O. Assessment of Knowledge, Perception about Transplantation and Life Changes in Renal Transplant Patients. Bagcilar Med Bull 2020;5(1):1-6

${ }^{\odot}$ Copyright 2020 by the Health Sciences University, Bagcilar Training and Research Hospital Bagcilar Medical Bulletin published by Galenos Publishing House. 


\section{Introduction}

Chronic kidney disease is a common disease that affects life negatively and can progress to end-stage renal disease (ESRD). Renal transplantation is the gold standard treatment option in these patients, even though renal function support with external interventions (hemodialysis and peritoneal dialysis) can be provided (1). Renal transplantation has many difficulties before, during and after the operation, but it is an ultimate step in the treatment of ESRD (2). Informing renal transplant patients about the difficulties they may face in this process and providing them with realistic expectations may make it easier for them to accept changes in life-style and could increase treatment compliance and success (3). In particular, the use of immunosuppressive drugs, which are essential after transplantation, is crucial for treatment success (4).

Various studies have examined the knowledge, perception about transplantation and life changes in the treatment of kidney transplantation patients. It has been shown that inadequately informed patients are more severely affected by the slightest negativity as a result of unrealistic expectations (5). In particular, it was emphasized that lack of knowledge and heightened expectations may lead to non-adherence to immunosuppressive treatments (4). At every stage of the kidney transplantation process, from the beginning to the present state, it is necessary to ensure healthy communication with healthcare providers $(6,7,8)$.

It is known that individual factors play an important role in the decision of transplantation and the success of treatment (9). The objective of this study was to determine subjective factors such as adherence to treatment, knowledge levels, individual perceptions and life-style changes, in order to determine variables that could be useful for future processes in patients undergoing kidney transplant.

\section{Material and Methods}

The study was approved by the İstanbul Yeniyüzyll University Clinical Research Ethics Committee (approval no: $2018 / 7$, date: 02.07 .2018 ). Fifty people aged between 18-70 years who were admitted to the Nephrology Clinic of Gaziosmanpaşa Hospital between January 2019 and November 2019 were included in the study. Inclusion criteria was: having undergone renal transplantation at least 3 months ago, and being treated as outpatients at our nephrology clinic. A semi-structured questionnaire including questions about their knowledge regarding transplantation, life-style changes in the transplantation process and personal perceptions, was administered to the patients. The questionnaire was administered under supervision and it was ensured that each individual completed the questionnaire without external assistance. The completion time of the questionnaire was approximately half an hour. Patients who accepted to participate the study were included in the study after they completed the questionnaire in full.

\section{Statistical Analysis}

All analyses were performed on SPSS v21 (SPSS Inc., Chicago, IL, USA). Data given as mean \pm standard deviation (minimum-maximum) for continuous variables and frequency (percentage) for categorical variables. The suitability of the numerical data for normal distribution was determined by the Shapiro-Wilk test. Pearson's chisquare test was used for comparison of categorical data and the Mann-Whitney $U$ test was used for comparison of continuous non-distributed data. Statistically, a p value less than 0.05 was considered significant.

\section{Results}

Sociodemographic characteristics are summarized in Table 1 . Twenty-four patients $(48 \%)$ were diagnosed with hypertension, 10 patients (20\%) were diagnosed with cardiologic problems, four patients $(8 \%)$ reported nausea and vomiting. The source of the transplanted kidneys was: 12 (24\%) cadaver, 10 (20\%) wife/husband, $10(20 \%)$ father, eight $(16 \%)$ mother, and five (10\%) non-blood-relative individuals. Time after transplantation was: less than 1 year in $20(40 \%)$ patients, $1-3$ years in nine $(18 \%), 3-5$ years in Table 1. Summary of patients characteristics

\begin{tabular}{lc} 
Age (year) & $40.34 \pm 13.44(18-69)$ \\
Gender & \\
Female & $22(44.00 \%)$ \\
Male & $28(56.00 \%)$ \\
Working status & $14(28.00 \%)$ \\
Working & $18(36.00 \%)$ \\
Not working (because of disease) & $18(36.00 \%)$ \\
Not working (unrelated with disease) & \\
Education status & $24(48.00 \%)$ \\
Primary school & $23(46.00 \%)$ \\
High school & $3(6.00 \%)$ \\
University & $31.18 \pm 14.97(8-64)$ \\
Disease starting age & $9.64 \pm 8.17(1-38)$ \\
Duration after diagnosis (year) & \\
\hline Data are given as mean \pm standard deviation (minimum - maximum) for \\
continuous variables and frequency (percentage) for categorical variables
\end{tabular}


six (12\%), and 5-10 years in 15 (30\%). Patients' knowledge and perceptions about transplantation are summarized in Table 2.

The most common causes of disturbance after transplantation were as follows: $10(20 \%)$ of the patients were not disturbed by anything in particular, 16 (32\%) were disturbed about medications and hospital visits, 13 (26\%) were complaining about diet and fluid restrictions, five $(10 \%)$ were worried about the disease, four $(8 \%)$ stated that they were disturbed by delayed normalization of blood values and two (4\%) reported that they were uncomfortable with the financial concerns. When the most positive aspects of transplantation were questioned: $22(44 \%)$ of the patients stated that there was no more dialysis in their life, 17 (34\%) stated that their health was better and their life was in order, six (12\%) felt more freedom, and three $(6 \%)$ stated that they had started working again. In regard to the source of family support: 24 (48\%) believed their mothers assisted the most, 16 (32\%) reported their wife/husband, eight (16\%) reported their brothers/sisters/children.

All patients expressed satisfaction with every step of the transplantation process. The reason for hospitalization in 39 patients (78\%) who stated that they were hospitalized after transplantation are as follows: persistence of renal problems (33.3\%), infection (30.8\%), drug side effects (15.4\%), non-adherence to medication (15.4\%), high creatinine values (5.13\%). Among the inpatients, 14 (40.0\%) had more physical activity after hospitalization, 12 (34.3\%) were more careful about diet and fluid intake, nine (25.7\%)

\begin{tabular}{|c|c|}
\hline \multicolumn{2}{|c|}{ Was the pre-treatment information provided to you, sufficient? } \\
\hline Yes & $44(88.00 \%)$ \\
\hline No & $6(12.00 \%)$ \\
\hline \multicolumn{2}{|l|}{ Thoughts about organ donation } \\
\hline Was positive & $35(70.00 \%)$ \\
\hline Was negative & $15(30.00 \%)$ \\
\hline \multicolumn{2}{|l|}{ Transplantation reason } \\
\hline To be freed of dialysis & $19(38.00 \%)$ \\
\hline Want to be more healthy & $31(62.00 \%)$ \\
\hline To start working again & $0(0.00 \%)$ \\
\hline \multicolumn{2}{|l|}{ What were your expectations regarding transplantation? } \\
\hline Returning back to the same life-style before disease & $17(34.00 \%)$ \\
\hline $\begin{array}{l}\text { I knew that i had to use medication and visit the } \\
\text { hospital regularly }\end{array}$ & $29(58.00 \%)$ \\
\hline Don't know/no expectations & $4(8.00 \%)$ \\
\hline
\end{tabular}

Data are given as frequency (percentage) reported better care for regular use of drugs. The effect of transplantation on patients is shown in Table 3.

Thirteen $(29.5 \%)$ of the 44 people who thought that they were informed sufficiently about transplantation and five (83.3\%) of the six people who thought that the information was not sufficient, stated that they had problems in treatment adherence. Those who reported not receiving adequate information before treatment had statistically significant problems with adherence to treatment $(\mathrm{p}=0.018)$. Men and people with at least one child were significantly more likely to have positive sexual life after transplantation $(\mathrm{p}<0.01)$. Those whose sexual life was positively affected had a significantly higher age at diagnosis $(\mathrm{p}=0.039)$ (Table 4). There were no statistically significant relationships between adherence problems to treatment, change in sex life, getting back to work or education, duration until achieving sufficient life quality, and the other variables measured (Table 4).

\section{Discussion}

The knowledge levels and perception of patients, adherence to treatment and changes in life-style are effective on the success of kidney transplantation. In this study, $86 \%$ of the patients who underwent kidney transplantation achieved an acceptable level of life quality after the operation and $36.7 \%$ stated that their sexual life changed positively. It was found that medication interruption was the most common problem after treatment (24\%), and that the sexual life of

\section{Table 3. The effect of transplantation on patients}

\section{Compliance problems}

None

$32(64.00 \%)$

Used drugs unregularly

$12(24.00 \%)$

Not visited hospital in time

$3(6.00 \%)$

Not applied diet and fluid restriction

$3(6.00 \%)$

Change in sexual life

Positive

$18(36.73 \%)$

Negative

$2(4.08 \%)$

No change

$29(59.18 \%)$

Got back to working

$20(40.00 \%)$

Got back to education

$9(18.00 \%)$

Duration until they reached sufficient life quality (after operation)

Not yet

$7(14.00 \%)$

1 month

$9(18.00 \%)$

2 months

$6(12.00 \%)$

3 months

$11(22.00 \%)$

$>3$ months

17 (34.00\%) 
men and also patients who had children were positively influenced by transplantation.

One of the most important results of our study was that patients who had been sufficiently informed prior to transplant had better treatment adherence. Alikari et al. (3) evaluated thelevel of knowledge regarding hemodialysis and adherence to treatment of chronic kidney disease patients, and organized an educational intervention to increase the level of knowledge. They stated that the level of knowledge and adherence to treatment increased with the educational intervention and this also increased patients' quality of life. In various studies, it has been shown that renal patients who are adequately informed about the disease and the process are more accepting and collaborative (10). It has been shown that not only adherence to treatment but also diet and fluid intake are influenced by the level of knowledge of patients with renal failure $(11,12)$. Since clinicians often do not have sufficient time, they generally choose to provide information regarding the transplant at a time which is very close to the planned operation. However, informing patients within the waiting period of the transplantation list is a critical practice that can both prolong the decisionmaking process and increase adherence to treatment. In addition, while informing these patients, it should be noted that cognitive deficits such as memory problems may be seen in this patient group (13).

In our study, patients reported the inability to use regular medication as the most common reason of non-adherence to therapy. Nevins et al. (4) examined these causes in kidney transplant patients and stated that meticulous adherence was an undeniable key step in the success of treatment. They stated that medication adherence could be associated with many factors, such as monitoring medications (electronic monitoring), being at a young age, being a member of a minority group, inadequate social support and health care. Several studies emphasized the importance of medication

Table 4. The difference in sexual life after transplantation

\begin{tabular}{llll} 
& $\begin{array}{l}\text { Positive } \\
\text { difference }\end{array}$ & $\begin{array}{l}\text { No or negative } \\
\text { difference }\end{array}$ & $\mathbf{p}$ \\
\hline $\begin{array}{l}\text { Gender } \\
\text { Female }\end{array}$ & $19(13.6)$ & 0.002 \\
Male & $15(55.6)$ & $12(44.4)$ & \\
Having a child & $16(55.2)$ & $13(44.8)$ & 0.001 \\
$\begin{array}{l}\text { Yes } \\
\text { No }\end{array}$ & $18(90.0)$ & 0.039 \\
Age at diagnosis & $32.5(22-57)$ & $24.0(8-64)$ & \\
\hline $\begin{array}{l}\text { Data are given as median (minimum-maximum) for continuous variables and } \\
\text { frequency (percentage) for categorical variables }\end{array}$
\end{tabular}

adherence for the healthy progression of the transplantation process $(14,15)$. The effect of various intervention programs on enhancing medication adherence after transplantation has been discussed in different studies and positive results have been reported $(16,17)$. In general, interventions include face-to-face or telephone conversations with healthcare professionals on various matters, including training, motivation, questioning features that prevent drug intake, and solving problems related to any of these factors $(6,7,8)$. Monitoring patients more closely and providing support in their time of need may have a positive influence on treatment adherence. In our study, different variables such as comorbid diseases and adverse living conditions that could affect drug adherence were not examined. In addition, incorrect interpretations may be made because drug compliance was determined by the patients' own statements.

It is very important to accurately understand the expectations of transplantation patients while informing them, in order to be able to shape patient expectations. In our study, one out of three patients stated that they expected to return to their pre-disease life after transplantation. Similarly, Calestani et al. (5) evaluated the expectations of patients on the kidney transplantation list and found that the majority of patients had the expectation of returning to normal life. Crawford et al. (18) stated that informing patients about difficulties and the things they should do before kidney transplantation enabled them to have a more realistic expectation about the treatment. It has been reported that patients with unrealistic expectations were psychologically affected by the difficulties encountered after transplantation and that the success of treatment was negatively affected as a result (19). Evaluating and managing the expectations of patients before and after the treatment is important for the success of treatment. In our study, pre-treatment information standardization could not be performed. For this reason, some patients may be more or less informed than others. Therefore, the lack of a standard for informing patients may have caused a bias in the assessment of results.

In our study, it was found that the sexual life of men and also patients who had children were significantly affected by transplantation. In various studies, the relationship between male sexual dysfunction and renal diseases have been shown, and it has been reported that hypogonadism may develop in about half of hemodialysis patients and testicular size may be reduced $(20,21)$. In addition, diseases such as hypertension and depression secondary 
to chronic kidney disease $(22,23)$, and medications (24) may affect sexual functions. In men with chronic kidney disease, vascular, endocrine and neurological problems, drugs used and additional diseases may cause erectile dysfunction and affect sexual functions and reduce libido (25). Studies have shown that renal transplantation leads to endocrine recovery (26) and reduces the incidence of erectile dysfunction $(26,27)$. In our study, it was thought that men had better sexual functions after transplantation for similar reasons. In addition, weight gain after kidney transplantation (28) and hair growth as a side effect of drugs may be increased (29). Body perception, is critical in sexual function; therefore, the possibility of obesity and hair growth increase in women after transplantation, could have negatively influenced their sex life. In our study, it was thought that a possible reason for the increased quality in the sexual life of patients who had children was associated with the fact that they were more significantly likely to be married.

In our study, more than half of the patients stated that they reached sufficient quality of life within 3 months. Kostro et al. (30) examined the quality of life of patients after renal transplantation and reported significant improvement in almost all aspects of the quality of life of all transplant patients, especially in peritoneal dialysis patients. Similarly, Balogun et al. (31) reviewed 23 previously published studies and reported that patients with ESRD had high expectations from dialysis and transplantation, in particular the quality of life of older patients was more negatively affected by kidney disease. Several different studies have also reported that renal transplantation is effective for patients to achieve a higher level of life quality compared to their pre-treatment status (32). In our study, the current life quality of patients may have been influenced by their perceptions regarding their life-style before the diagnosis of kidney disease and also the period that they were undergoing dialysis. Patients who based their expectancy onlife quality during dialysis may have been more positive about the consequences of transplantation; whereas those who referenced it with the pre-diagnosis status may have responded more negatively. It can be said that healthy communication of patients and healthcare providers has positive effects on all results examined in this study (30).

There are several limitations of this study in addition to the ones mentioned throughout the discussion. Firstly, since the data are based on patient statements, there may be subjective differences between responses. Secondly, due to the limited number of patients and lack of cross-sectional features, it is not appropriate to generalize the results. Thirdly, in some other studies, the effects of conditions such as quality of life and sexual functions were determined by standard index and scales. In this study, patient declarations were recorded directly. Finally, various additional diseases that may alter the results or other conditions that may have a positive/negative effect on life quality, were not assessed.

\section{Conclusion}

Increasing pre-treatment knowledge levels and managing the perceptions and expectations of patients planning to undergo kidney transplant can improve the adherence to treatment and critically affect treatment success. It was found that the quality of life of patients improved significantly after kidney transplantation. Men's sexuality was more positively affected by transplantation, explained by previous studies that demonstrate the negative impact of kidney diseases on male sexuality. We believe that, by endeavoring to improve patients' knowledge and perceptions prior to kidney transplantation, patient satisfaction and adherence to treatment can be significantly improved.

\section{Ethics}

Ethics Committee Approval: İstanbul Yeniyüzyll University Clinical Research Ethics Committee (Approval no: 2018/7, date: 02.07.2018).

Informed Consent: Patients who accepted to participate the study were included in the study after they completed the questionnaire in full.

Peer-review: Internally peer-reviewed.

Financial Disclosure: The authors declared that this study received no financial support.

\section{References}

1. Rosaasen N, Mainra R, Shoker A, Wilson J, Blackburn D, Mansell H. Education Before Kidney Transplantation: What Do Patients Need to Know? Progress in Transplantation 2017;27:58-64.

2. Been-Dahmen JMJ, Grijpma JW, Ista E, Dwarswaard J, Maasdam L, Weimar W, et al. Self-management challenges and support needs among kidney transplant recipients: A qualitative study. J Adv Nurs 2018;74:2393-2405.

3. Alikari V, Matziou V, Tsironi M, Theofilou P, Zyga S. The effect of nursing counseling on improving knowledge, adherence to treatment and quality of life of patients undergoing hemodialysis. International Journal of Caring Sciences 2015;8:514-518.

4. Nevins TE, Nickerson PW, Dew MA. Understanding Medication Nonadherence after Kidney Transplant. J Am Soc Nephrol 2017;28:2290-2301. 
5. Calestani M, Tonkin-Crine S, Pruthi R, Leydon G, Ravanan R, Bradley JA, et al ; ATTOM Investigators. Patient attitudes towards kidney transplant listing: qualitative findings from the ATTOM study. Nephrol Dial Transplant 2014;29:2144-2150.

6. Breu-Dejean N, Driot D, Dupouy J, Lapeyre-Mestre M, Rostaing L. Efficacy of Psychoeducational Intervention on Allograft Function in Kidney Transplant Patients: 10-Year Results of a Prospective Randomized Study. Exp Clin Transplant 2016;14:38-44.

7. Cukor D, Ver Halen N, Pencille M, Tedla F, Salifu M. A Pilot Randomized Controlled Trial to Promote Immunosuppressant Adherence in Adult Kidney Transplant Recipients. Nephron 2017;135:6-14.

8. Reese PP, Bloom RD, Trofe-Clark J, Mussell A, Leidy D, Levsky S, et al. Automated Reminders and Physician Notification to Promote Immunosuppression Adherence Among Kidney Transplant Recipients: A Randomized Trial. Am J Kidney Dis 2017;69:400-409.

9. Bozkurt O, Uyar M, Demir ÜF. Determination of Health Anxiety Level in Living Organ Donation. Transplant Proc 2019;51:11391142.

10. Devins GM, Mendelssohn DC, Barre PE, Taub K, Binik YM. Predialysis psychoeducational intervention extends survival in CKD: a 20-year follow-up. Am J Kidney Dis 2005;46:1088-1098.

11. Afifi A, El-Sayed H, El-Setouhi M, Ahmed H, Khalifa N. Hyperphosphatemia among end-stage renal disease patients in developing countries: a forgotten issue? Hemodial Int 2005;9:409415.

12. Lee SH, Molassiotis A. Dietary and fluid compliance in Chinese hemodialysis patients. Int J Nurs Stud 2002;39:695-704.

13. Kurella Tamura M, Yaffe K. Dementia and cognitive impairment in ESRD: diagnostic and therapeutic strategies. Kidney Int 2011;79:14-22.

14. Wiebe C, Gibson IW, Blydt-Hansen TD, Pochinco D, Birk PE, Ho $\mathrm{J}$, et al. Rates and determinants of progression to graft failure in kidney allograft recipients with de novo donor-specific antibody. Am J Transplant 2015;15:2921-2930.

15. Wiebe C, Gibson IW, Blydt-Hansen TD, Karpinski M, Ho J, Storsley LJ, et al. Evolution and clinical pathologic correlations of de novo donor-specific HLA antibody post kidney transplant. Am J Transplant 2012;12:1157-1167.

16. Conn VS, Ruppar TM, Chase JA, Enriquez M, Cooper PS. Interventions to Improve Medication Adherence in Hypertensive Patients: Systematic Review and Meta-analysis. Curr Hypertens Rep 2015;17:94.

17. Demonceau J, Ruppar T, Kristanto P, Hughes DA, Fargher E, Kardas $\mathrm{P}$, et al. Identification and assessment of adherence-enhancing interventions in studies assessing medication adherence through electronically compiled drug dosing histories: a systematic literature review and meta-analysis. Drugs 2013;73:545-562.

18. Crawford K, Low JK, Manias E, Williams A. Healthcare professionals can assist patients with managing post-kidney transplant expectations. Res Social Adm Pharm 2017;13:1204-1207.
19. De Pasquale C, Veroux M, Indelicato L, Sinagra N, Giaquinta A, Fornaro M, et al. Psychopathological aspects of kidney transplantation: Efficacy of a multidisciplinary team. World J Transplant 2014;4:267-275.

20. Kyriazis J, Tzanakis I, Stylianou K, Katsipi I, Moisiadis D, Papadaki A, et al. Low serum testosterone, arterial stiffness and mortality in male haemodialysis patients. Nephrol Dial Transplant 2011;26:2971-2977.

21. Gungor O, Kircelli F, Carrero JJ, Asci G, Toz H, Tatar E, et al. Endogenous testosterone and mortality in male hemodialysis patients: is it the result of aging? Clin J Am Soc Nephrol 2010;5:20182023.

22. Vecchio M, Palmer S, De Berardis G, Craig J, Johnson D, Pellegrini F, et al. Prevalence and correlates of erectile dysfunction in men on chronic haemodialysis: a multinational cross-sectional study. Nephrol Dial Transplant 2012;27:2479-2488.

23. Kupelian V, Page ST, Araujo AB, Travison TG, Bremner WJ, McKinlay JB. Low sex hormone-binding globulin, total testosterone, and symptomatic androgen deficiency are associated with development of the metabolic syndrome in nonobese men. J Clin Endocrinol Metab 2006;91:843-850.

24. Carrero JJ, Qureshi AR, Nakashima A, Arver S, Parini P, Lindholm $\mathrm{B}$, et al. Prevalence and clinical implications of testosterone deficiency in men with end-stage renal disease. Nephrol Dial Transplant 2011;26:184-190.

25. Edey MM. Male Sexual Dysfunction and Chronic Kidney Disease. Front Med (Lausanne) 2017;4:32.

26. Teng LC, Wang CX, Chen L. Improved erectile function and sex hormone profiles in male Chinese recipients of kidney transplantation. Clin Transplant 2011;25:265-269.

27. Mota RL, Fonseca R, Santos JC, Covita AM, Marques N, Matias P, et al. Sexual Dysfunction and Satisfaction in Kidney Transplant Patients. J Sex Med 2019;16:1018-1028.

28. LaGuardia H, Zhang R. Obesity and metabolic syndrome in kidney transplantation. Curr Hypertens Rep 2013;15:215-223.

29. Vergoulas G, Eleftheriadis T, Avdelidou A, Ioannou K, Miserlis G, Solonaki F, et al. Body dysmorphic disorder due to hirsutism in a patient treated with cyclosporin. Nephrol Dial Transplant 2005;20:473.

30. Kostro JZ, Hellmann A, Kobiela J, Skora I, LichodziejewskaNiemierko M, Debska-Slizien A, et al. Quality of Life After Kidney Transplantation: A Prospective Study. Transplant Proc 2016;48:5054.

31. Balogun SA, Balogun R, Philbrick J, Abdel-Rahman E. Quality of Life, Perceptions, and Health Satisfaction of Older Adults with End-Stage Renal Disease: A Systematic Review. J Am Geriatr Soc 2017;65:777-785.

32. Butt Z, Yount SE, Caicedo JC, Abecassis MM, Cella D. Quality of life assessment in renal transplant: review and future directions. Clin Transplant 2008;22:292-303. 